\title{
Prostate Cancer cT2 TNM Finding v8
}

National Cancer Institute

\section{Source}

National Cancer Institute. Prostate Cancer CT2 TNM Finding v8. NCI Thesaurus. Code C140134.

Prostate cancer in which the tumor is palpable and confined within the prostate. (from AJCC 8th Ed.) 